\title{
Penerapan Model Pembelajaran Saintifik Approacd Berbasis Media Pembelajaran Kearifan Lokal pada Mata Kuliah Dasar-Dasar Sosiologi dalam Membangun Karakter dan Meningkatkan Hasil Belajar Mahasiswa Pendidikan Sosiologi Universitas Muhammadiyah Makassar
}

\author{
Suardi ${ }^{1)} \&$ Syarifuddin ${ }^{2)}$ \\ Pendidikan Sosiologi FKIP Universitas Muhammadiyah Makassar ${ }^{1)}$ \\ Pendidikan Sosiologi FKIP Universitas Muhammadiyah Makassar 2) \\ suardi@unismuh.ac.id ${ }^{1)}$ \& syarifuddin@unismuh.ac.id ${ }^{2)}$
}

\begin{abstract}
The research objective is to analyze student activity during the learning process (ii) analyze student learning outcomes (iii) identify emerging character values (iv) identify obstacles that arise when applying the scientific approach learning model through learning media of local wisdom through classroom action research ( class room action research) for class A students in 2018. Student learning outcomes through the application of comparative scientific approach learning models in cycle I achieved classical completeness only reached $65.37 \%$ and in the second cycle had increased to $92.30 \%$ of the standard $90 \%$ completeness and reached KKM value 85 . Student activity in the learning process in the first cycle was very high reaching 80.11 and cycle II which was 91.79 had reached the standard of $90 \%$. Reflections on cycles I and II include the learning process using approacd scientific learning models, lecture contracts, dress rules, evaluation of learning, classroom use and publications on blogs so as to correct deficiencies of cycle I to cycle II. The results of the majority student questionnaire said (a) It was very pleasant with the application of the application of the scientific learning model approacd (b) Media classroom had grown the character of students' discipline and responsibility (c) Lecturers were very pleasant.

Keywords: scientific approach, learning media, local wisdom, character
\end{abstract}

\begin{abstract}
Abstrak. Tujuan penelitian untuk menganalisis keaktifan mahasiswa pada saat proses pembelajaran (ii) menganalisis hasil belajar mahasiswa (iii) mengidentifikasi nilai-nilai karakter yang muncul (iv) mengidentifikasi kendala yang muncul saat penerapan model pembelajaran scientific approach melalui media pembelajaran kearifan local melalui penelitian tindakan kelas (class room action research) pada mahasiswa kelas A angkatan 2018. Hasil belajar mahasiswa melalui penerapan model pembelajaran scientific approach perbandingan pada siklus I mencapai ketuntasan klasikal hanya mencapai $65.37 \%$ dan pada siklus II sudah mengalami peningkatan sampai $92.30 \%$ dari standar ketuntasan klasikal 90\% dan mencapai nilai KKM 85. Keaktifan mahasiswa dalam proses pembelajaran pada siklus I sangat tinggi mencapai 80.11 dan siklus II yaitu 91.79 sudah mencapai standar $90 \%$. Refleksi siklus I dan II mencakup proses pembelajaran menggunakan model pembelajaran saintifik approacd, kontrak perkuliahan, aturan berpakaian, evaluasi pembelajaran, penggunaan classroom dan publikasi pada blog-blog agar dapat memperbaiki kekurangan dari siklus I menuju siklus II. Hasil angket mahasiswa mayoritas mengatakan (a) Sangat menyenangkan dengan diterapkannya penerapan model pembelajaran saintifik approacd (b) Media classroom telah menumbuhkan karakter disiplin dan tanggung jawab mahasiswa (c) Dosen mengajar sangat menyenangkan.

Kata Kunci: scientific approach, media pembelajaran, kearifan lokal, karakter
\end{abstract}




\section{PENDAHULUAN}

Pemilihan topik penelitian yang akan dilakukan berdasarkan hasil pengamatan yang dilakukan selama 1 Tahnu terakhir di kampus Universitas Muhammadiyah terkhusus pada Program Studi Pendidikan Sosiologi, yaitu banyaknya mahasiswa yang tidak memiliki Nilainilai karakter. Pembentukan karakter mahasiswa merupakan salah satu masalah yang tengah hangat diperbincangkan dalam dunia pendidikan. Masalah seperti pencurian, pembunuhan, pemerkosaan, dll semakin marak terjadi di masyarakat. Kriminalitas tidak hanya datang dari kalangan kelas ekonomi rendah, tetapi dari kalangan atas. Para pemimpin bangsa yang seharusnya memberikan panutan malah menjadi pelaku dalam kasus kriminalitas.

Mahasiswa sebagai generasi penerus bangsa pun sudah mulai membentuk karakter yang tidak baik. Dari berbagai hasil penelitian tentang buruknya karakter mahasiswa tidak hanya ditandai oleh kasus-kasus besar seperti konflik mahasiswa (Kusnarwatiningsih, A 2003), demonstrasi yang berujung pada tidakan anarkis (Barata, M. F. M. 2013), seks bebas (Zulfikar, F. 2014), atau penggunaan narkoba (Hakim, P. P. 2014). tetapi dari masalah- masalah kecil yang lazim terjadi dalam lingkungan kampus seperti mencontek pada saat ujian (Nursalam, N., Bani, S., \& Munirah, M. 2013). Sedangakan Berdasarkan data dari beberapa dosen, banyak ditemukan kasus-kasus penyimpangan yang dilakukan mahasiswa, kasus penyimpangan yang sering dilakukan mahasiswa diantaranya seperti datang terlambat, merokok, perkelahian sesama teman dikampus atau lain kampus dan lain-lain. Banyaknya kasus perilaku yang menyimpang ini menunjukkan bahwa nilai-nilai moral perlu ditingkatkan di lingkungan kampus. Nilai-nilai moral yang ditanamkan ini diharapkan dapat membentuk karakter mahasiswa yang berperilaku baik dalam hidup bermasyarakat.

Pembentukan karakter mahasiswa sesuai dengan (1) Renstra (Rencana Strategis) kementerian pendidikan Nasional (sekarang Kementerian Pendidikan dan Kebudayaan) 2010-
2014 telah mencanangkan penerapan pendidikan karakter untuk seluruh jenjang pendidikan di Indonesia mulai tingkat Pendidikan anak Usia Dini (PAUD) sampai perguruan Tinggi (PT) dalam sistem pendidikan di Indonesia. (2) Kebijakan nasional pembangunan karakter bangsa ini disusun sebagai pelaksanaan amanat UU RI No.17 tahun 2007 tentang Rencana Pembangunan Jangka Panjang Nasional Tahun 2005-2025. (3) Program Pemeritah Indonesia 2014-2015 mencanangkan revolusi karakter bangsa sebagai salah satu program strategis yang perlu dicermati bersama sebagai salah satu tanggung jawab perguruan tinggi.

Penanaman nilai-nilai karakter seharusnya pada materi kuliah dapat ditanamkan oleh dosen melalui pembelajaran yang dilakukan. Kegiatan pembelajaran yang mencerminkan pembentukan karakter hendaknya direncanakan dengan matang dalam rencana pelaksanaan pembelajaran. Mata kuliah dasar-dasar sosiologi merupakan salah satu mata kuliah yang dapat dikembangkan untuk membentuk karakter mahasiswa, karena melalui mata kuliah tersebut, mahasiswa bisa memahami nilai-nalai kearifan lokal yang juga bisa mendukung pembentukan karakter mahasiswa. selain dari nilai-nilai kearifan lokal pembentukan karakter bisa ditanamkan melalui model pembelajaran yang diterapkan dosen saat proses perkuliahan berlangsung. Berkaitan dengan hal tersebut, perlu kiranya dirumuskan model pembelajaran yang dapat mengakomodasi dua hal, yaitu (a) penyampaian substansi materi sesuai dengan matapelajaran yang diajarkan dan (b) sekaligus mampu menjadi wadah pengembangan nilai- nilai karakter.

Salah satu model atau pendekatan yang dianggap mampu untuk menanamkan nilai- nilai karakter dalam pembelajaran terkhusus pada mata kuliah dasar-dasar sosiologi adalah model pembelajaran scientific approach. Penelitian tentang penggunaan pendekatan scientific

approach pada mahasiswa dan pada mata kuliah atau pelajaran IPS (sosiologi), pernah dilakukan oleh beberap peneliti seperti yang dilakukan Wijayanti, A. (2014) tentang Pengembangan autentic assesment berbasis 
proyek dengan pendekatan scientific approach. untuk meningkatkan keterampilan berpikir ilmiah mahasiswa. Hasil penelitiannya menunjukkan pendekatan scientific approach sangat baik diterapkan dalam proses pembelajaran. Hasil penelitian yang lain yaitu penelitian yang dilakukan Towaf, S. M. (2014). Tentang pendidikan karakter pada mata pelajaran ilmu pengetahuan sosial melalui pendekatan scientific approach. Hasil penelitiaanya menujukkan adanya karakter yang muncul setelah penerapan pendekatan scientific approach dalam pembelajaran. Atas dasar tersebut maka perlu dilakukan suatu penelitian penerapan scientific approach pada mata kuliah dasar-dasar sosiologi yang mempu mengembangkan nilai-nilai karekter mahasiswa dan nilai-nilai kearifan lokal dalam mata kuliah.

Penelitian ini sangat penting guna menanamkan karekter kepada mahasiswa melalui pendekatan ilmiah dengan memanfaatkan kearfian lokal masyarakat agar pembelajaran lebih kontektual dengan kehidupan mahasiswa dan untuk mengoptimalkan kearifan lokal dalam membangun pendidikan karakter bagi mahasiswa, maka pembelajaran dikembangkan dengan menggunakan multimedia pembelajaran seperti gambar, url video, peta konsep, kasus, ilustrasi, diagram, tabel, lirik lagu, contoh film dan lain-lain, agar dapat menarik perhatian mahasiswa dalam pembelajaran. Dengan penelitian ini diharapkan terbentuknya karakter mahasiswa setelah melalui proses pembelajaran pada mata kuliah dasardasar sosiologi melalui pendekatan scientific approach dan nilai-nilai kearifan melalui pemanfaatan media pembelajaran yang lebih komunikatif.

\section{METODE PENELITIAN}

\section{Jenis Penelitian}

Penelitin ini termasuk penelitian deskriptif yang didesain melalui penelitian tindakan kelas (class room action research) yang bertujuan mendeskripsikan peningkatan hasil belajar dan keaktifan mahasiswa dalam pembelajaran pada mata kuliah Dasar-Dasar Sosiologi melalui model pembelajaran model pembelajaran scientific approach pada mahasiswa kelas A Angakatan 2018 yang terdiri atas empat tahap yaitu perencanaan, pelaksanaan tindakan, observasi, dan refleksi yang digambarkan sebagai berikut:

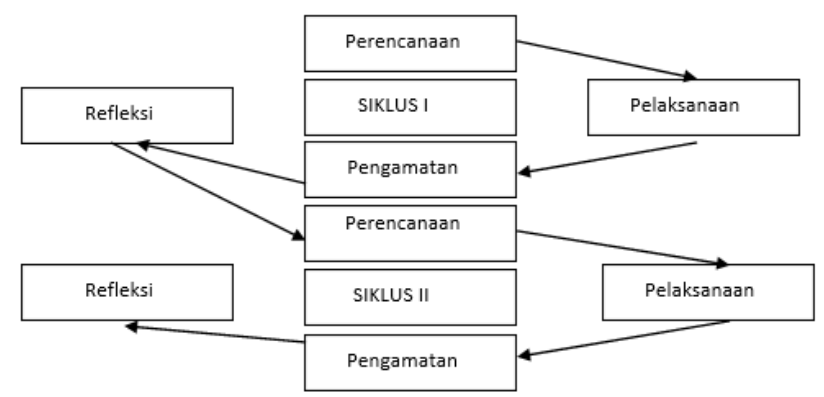

Bagan .3.1: Pelakasanaan Tindakan Menurut Suharsimi Arikunto (2010)

\section{Subjek, Tempat, dan Waktu Penelitian}

Subjek penelitian ini mahasiswa kelas A angkatan 2018. Penelitian ini dilaksanakan di Universitas Muhammadiyah Makassar Fakultas Keguruan dan Ilmu Pendidikan Program Studi Pendidikan Sosiologi. Waktu penelitian akan dilakukan selama 1 tahun mulai tahun 2018-2019.

\section{Prosedur Penelitian}

Penelitian tindakan kelas ini direncanakan sebanyak dua siklus, tiap siklus dilaksanakan sesuai perubahan yang ingin dicapai. Siklus I dilaksanakan dengan 4 kali pertemuan, 3 kali pertemuan ( 2 jam pembelajaran), tatap muka dan 1 kali pertemuan untuk evaluasi hasil belajar. Siklus II dilaksanakan dengan 4 kali pertemuan, 3 kali pertemuan ( 2 jam pembelajaran), untuk tatap muka dan 1 kali pertemuan untuk evaluasi hasil belajar.

\section{Instrumen Penelitian}

Instrumen yang digunakan untuk mengumpulkan data dalam penelitian ini adalah:

1. Tes hasil belajar digunakan untuk memperoleh informasi tentang penguasaan materi kuliah oleh mahasiswa, yaitu mengukur aspek kognitif mahasiswa.

2. Lembar observasi digunakan untuk mengetahui data tentang keaktifan mahasiswa dalam mengikuti proses pembelajaran yaitu aktif mengamati, menanya, mengumpulkan informasi, mengelolah informasi dan 
mengkomunikasikan.

3. Lembar skala sikap untuk mengetahui karakter yang muncul dalam diri mahasiswa saat proses dan setelah proses pembelajaran yaitu karakter disiplin dan tanggung-jawab.

4. Angket digunakan untuk mengumpulkan data tentang respons mahasiswa terhadap model pembelajaran yang diterapkan yaitu model pembelajaran scientific approach

\section{Teknik Analisis Data}

Data yang diperoleh akan dianalisis dengan menggunakan analisis kualitatif dan kuantitatif. Data kuantitatif yang dapat dianalisis secara deskriptif misalnya mencari nilai rata-rata, persentase keberhasilan dan lain-lain. Sedankan data kualitatif yaitu data yang berupa informasi berbentuk kalimat yang memberi gambaran tentang tingkat pemahaman siswa terhadap mata kuliah dalam hal ini mata kuliah Dasar-Dasar Sosiologi, pandangan atau sikap mengikuti pelajaran, perhatian, antusias dalam belajar, kepercayaan diri, motivasi belajar dan sebagainya dapat dianalisa secara kualitatif (Arikunto (2010). Adapun untuk keperluan data kuantitatif, yang disesuaikan dengan data tes belajar mahasiswa dihitung dengan cara sebagai berikut.

1. Data hasil tes

Nilai $=\quad$ Jumlah skor yang dijawab benar $\times 100 \%$ Skor maksimal|

2. Nilai rata-rata Nilai rata-rata siswa $=\underline{\text { Jumlah nilai mahasiswa }}=$ Banyaknya mahasiswa

\begin{tabular}{ccc}
\hline No. & Nilai & Kategori \\
\hline 1. & $0-34$ & Sangat rendah Rendah \\
2. & $35-54$ & Sedang Tinggi \\
3. & $55-64$ & Sangat tinggi \\
4. & $65-84$ & \\
5. & $85-100$ & \\
\hline
\end{tabular}

\section{Indikator Keberhasilan}

Indikator keberhasilan penelitian tindakan kelas ini adalah apabila terjadi peningkatan dan ketuntasan proses pembelajaran dengan menerapkan model pembelajaran scientific approach melalui media pembelajaran kearifan local pada mata kuliah Dasar- Dasar Sosologi Program Studi Pendidikan Sosiologi. Indikator kinerja dalam penelitian ini adalah (1) Ketuntasa secara individual mahasiswa mencapai 85 (minimal B), (2) keaktifan mahasiswa dalam pembelajaran mencapai $90 \%$, (3) ketuntasan secara klasikal mencapai $90 \%$, (4) karakter yang muncul minimal 1 karakter yaitu antara karakter disiplin dan tanggung-jawab.

\section{PEMBAHASAN}

\section{Deskripsi Siklus I}

Penelitian yang bertujuan menggambarkan penerapan model pembelajaran saintifik approacd yang berbasis media pembelajaran kearifan local pada mata kuliah dasar-dasar sosiologi dalam membangun karakter dan meningkatkan hasil belajar mahasiswa Pendidikan Sosiologi Fakultas Kedosenan dan Ilmu Pendidikan Universitas Muhammadiyah Makassar. Pada siklus I dilaksanakan selama empat kali pertemuan, tiga kali pertemuan membahas materi perkuliahan dasar-dasar sosiologi dan satu pertemuan untuk melakukan evaluasi. Pada akhir pertemuan dilaksanakan tes hasil belajar yang berbentuk tes essay setelah selesai penyajian materi dasar-dasar sosiologi. Dari analisis deskriptif nilai hasil disajikan pada tabel 1.1 berikut:

Tabel 1.1 Statistik Skor Hasil Tes Siklus I

\begin{tabular}{|c|c|}
\hline Statistik & Nilai Statistik \\
\hline Subjek & 26 \\
\hline Skor Ideal & 100 \\
\hline Skor Tertinggi & 95 \\
\hline Skor Terendah & 0 \\
\hline Rentang Skor & 95 \\
\hline Skor Rata-rata & 79.23 \\
\hline
\end{tabular}

Apabila nilai hasil belajar penerapan model pembelajaran saintifik approacd yang berbasis media pembelajaran kearifan local pada mata kuliah dasar-dasar sosiologi dalam membangun karakter dan meningkatkan hasil belajar mahasiswa Pendidikan Sosiologi Fakultas Keguruan dan IImu Pendidikan Universitas Muhammadiyah Makassar dikelompokkan ke dalam lima kategori, maka diperoleh distribusi frekuensi yang ditunjukkan pada tabel 1.2 berikut ini: 
Tabel 1.2 Distribusi Frekuensi dan Persentase Skor Hasil Tes pada Siklus I

\begin{tabular}{|c|c|c|c|}
\hline $\begin{array}{c}\text { Interval } \\
\text { Skor }\end{array}$ & Kategori & Frek & (\%) \\
\hline $\mathbf{0 - 3 4}$ & $\begin{array}{c}\text { Sangat } \\
\text { Rendah }\end{array}$ & 1 & $3.86 \%$ \\
\hline $\mathbf{3 5 - 5 4}$ & Rendah & 1 & $3.86 \%$ \\
\hline $\mathbf{5 5 - 6 4}$ & Sedang & 7 & $26.93 \%$ \\
\hline $\mathbf{6 5 - 8 4}$ & Tinggi & 6 & $23.04 \%$ \\
\hline $\mathbf{8 5 - 1 0 0}$ & $\begin{array}{c}\text { Sangat } \\
\text { Tinggi }\end{array}$ & 11 & $42.31 \%$ \\
\hline Jumlah & \multicolumn{2}{|c|}{26} & $100 \%$ \\
\hline
\end{tabular}

Hasil analisis deskriptif di atas menunjukkan bahwa ketuntasan hasil belajar penerapan model pembelajaran saintifik approacd yang berbasis media pembelajaran kearifan local pada mata kuliah dasar-dasar sosiologi pada siklus I masih perlu perbaikan karena asih ada 17 mahasiswa yang mendapatkan nilai dibawah standar yang diharapkan. Dapat dilihat pada diagram 1.1 berikut

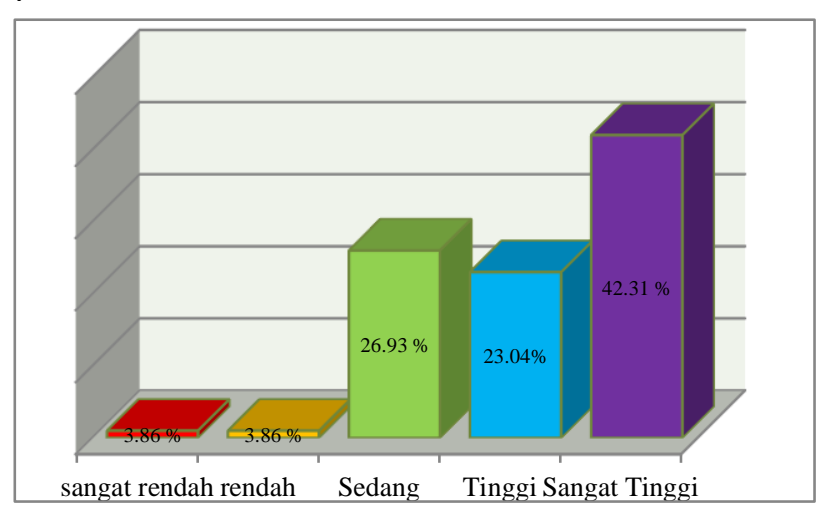

Diagram 4.1 Hasil Belajar Siklus I

Berdasarkan tabel 1.2. dan diagram 1.1 maka distribusi frekuensi, persentase, serta kategori ketercapaian ketuntasan hasil belajar penerapan model pembelajaran saintifik approacd yang berbasis media pembelajaran kearifan local pada mata kuliah dasar-dasar sosiologi dalam membangun karakter dan meningkatkan hasil belajar mahasiswa Pendidikan Sosiologi Fakultas Keguruan dan IImu Pendidikan Universitas Muhammadiyah Makassar pada siklus I yang mencapai ketuntasan 65.37 yang bermakna ada 17 mahasiswa yang mencapai nilai dan masih ada 9 mahasiswa atau 34.63 \% yang belum mencapai nilai yang diharapkan. Selengkapnya dapat ditunjukkan pada diagram 1.2 berikut:

\section{Diagram 1.2. Ketuntasan Hasil Belajar Siklus I}

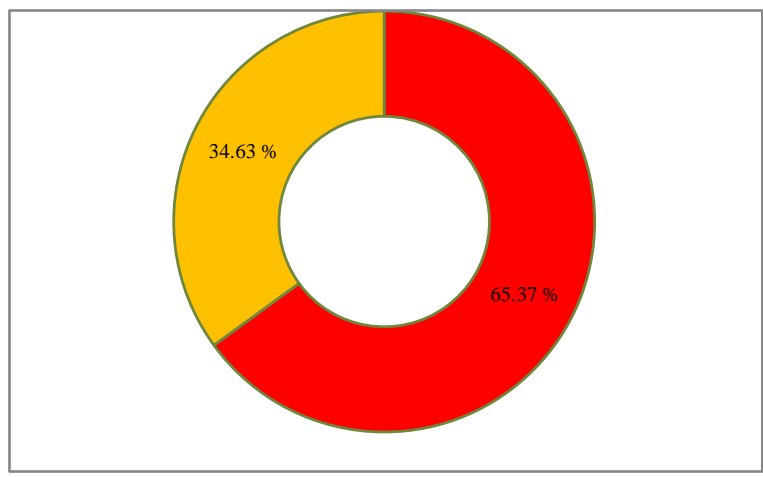

Berdasarkan kriteria hasil belajar pada siklus I maka klasikal pada siklus I belum mencapai standar yang telah ditetapkan yaitu $90 \%$ sedangkan mahasiswa yang mencapai ketuntasan klasikal hanya 61.55. Sedangkan untuk kriteria ketuntasan individual hanya 10 orang mahasiswa atau $38.45 \%$ yang mencapai kriteria ketuntasan minimal. Penelitian ini perlu dilanjutkan pada siklus berikutnya karena berdasarkan tujuan yang ingin dicapai, yaitu peningkatan hasil belajar mahasiswa pada mata kuliah dasar-dasar sosiologi belum terlihat.

\section{Deskripsi Siklus II}

Pada akhir pertemuan dilaksanakan tes hasil belajar yang berbentuk final tes setelah selasai penyajian pembahasan dasar-dasar sosiologi. Dari analisis deskriptif nilai hasil belajar mahasiswa melalui penerapan model pembelajaran saintifik approacd mahasiswa Pendidikan Sosiologi Fakultas Keguruan dan Ilmu Pendidikan Universitas Muhammadiyah Makassar pada Siklus II disajikan pada tabel 1.3 berikut:

Tabel 1.3 Statistik Skor Hasil Tes Siklus II.

\begin{tabular}{|c|c|}
\hline Statistik & Nilai Statistik \\
\hline Subjek & 26 \\
\hline Skor Ideal & 100 \\
\hline Skor Tertinggi & 100 \\
\hline Skor Terendah & 0 \\
\hline Rentang Skor & 100 \\
\hline Skor Rata-rata & 85 \\
\hline
\end{tabular}


Apabila nilai hasil belajar mahasiswa pada mata kuliah dasar-dasar sosiologi dikelompokkan ke dalam lima kategori, maka diperoleh distribusi frekuensi yang ditunjukkan pada tabel 1.4 berikut ini:

\section{Tabel 1.4 Distribusi Frekuensi Siklus II}

\begin{tabular}{|c|c|c|c|}
\hline $\begin{array}{c}\text { Interval } \\
\text { Skor }\end{array}$ & Kategori & Frek & (\%) \\
\hline $\mathbf{0 - 3 4}$ & Sangat Rendah & 1 & $3.85 \%$ \\
\hline $\mathbf{3 5 - 5 4}$ & Rendah & 0 & $0 \%$ \\
\hline $\mathbf{5 5 - 6 4}$ & Sedang & 1 & $3.85 \%$ \\
\hline $\mathbf{6 5 - 8 4}$ & Tinggi & 9 & $34.61 \%$ \\
\hline $\mathbf{8 5 - \mathbf { 1 0 0 }}$ & Sangat Tinggi & 15 & $57.69 \%$ \\
\hline Jumlah & 26 & & $100 \%$ \\
\hline
\end{tabular}

Hasil analisis deskriptif di atas menunjukkan peningkatan hasil belajar mahasiswa pada mata kuliah dasar-dasar sosiologi melalui penerapan model pembelajaran saintifik approacd pada Mahasiswa mahasiswa Pendidikan Sosiologi Fakultas Keguruan dan Ilmu Pendidikan Universitas Muhammadiyah Makassar bahwa siklus II dikategorikan dapat dilihat pada diagaram 1.3 berikut :

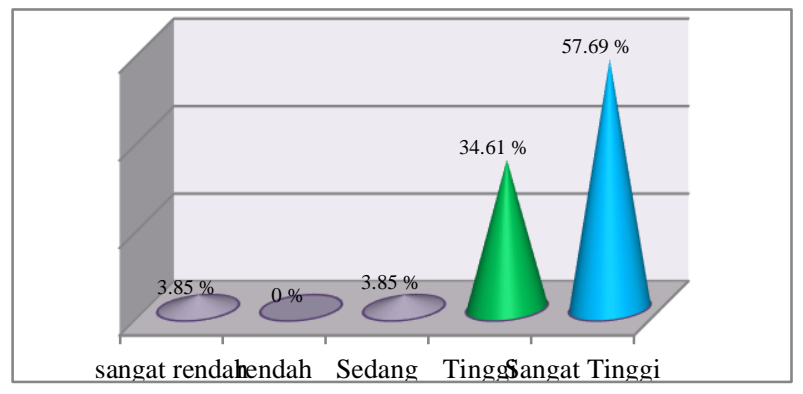

\section{Diagram 1.3 Hasil Belajar Siklus II}

Berdasarkan tabel 4.4. dan diagram 4.3 di atas, distribusi frekuensi, persentase, serta kategori ketercapaian ketuntasan hasil belajar mahasiswa pada siklus II sebanyak $92.30 \%$ dan yang tidak tuntas hanya $7.70 \%$ Selengkapnya dapat ditunjukkan pada diagram 1.4 berikut:

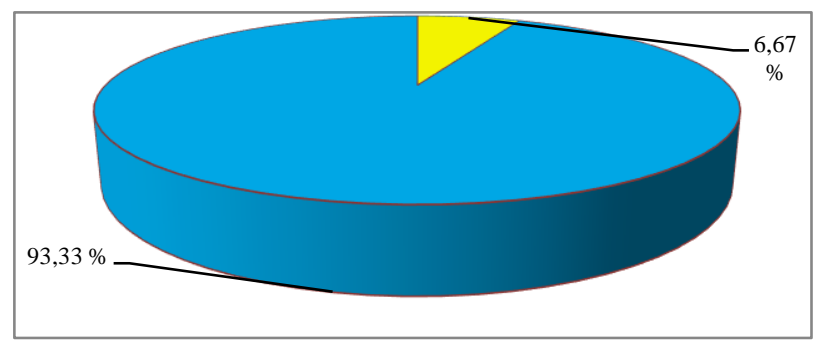

Diagram 1.4. Ketuntasan Hasil Belajar Siklus II
Berdasarkan kriteria hasil belajar mengenai ketuntasan kelas, yaitu $95 \%$, data hasil penelitian pada siklus dua di atas dianggap tuntas kelas di mana yang tuntas mencapai $92.30 \%$ atau 24 orang dari 26 orang mahasiswa dan hanya 2 orang atau $7.70 \%$ mahasiswa yang berada pada kategori tidak tuntas atau memiliki nilai dibawah nilai B. Kerana 1 orang mahasiswa memiliki nilai $\mathrm{C}$ dan 1 orang mahasiswa memiliki nilai E. Penelitian ini tidak perlu dilanjutkan pada siklus berikutnya karena berdasarkan tujuan yang ingin dicapai, yaitu peningkatan hasil belajar sudah terlihat, maka peneliti menganggap penelitian ini sudah cukup dengan menyimpulkan bahwa terjadi peningkatan hasil belajar mahasiswa pada mata kuliah dasardasar sosiologi yang sangat signifikan melalui penerapan model pembelajaran saintifik approacd pada mahasiswa Pendidikan Sosiologi Fakultas Keguruan dan Ilmu Pendidikan Universitas Muhammadiyah Makassar.

Berdasarkan analisis hasil belajar mahasiswa pada mata kuliah dasar-dasar sosiologi siklus I dan siklus II perbandingan ketuntasan hasil belajar tes siklus I dan ketuntasan hasil belajar tes siklus II melalui penerapan model pembelajaran saintifik approacd dapat dilihat pada diagram 1.5 berikut:

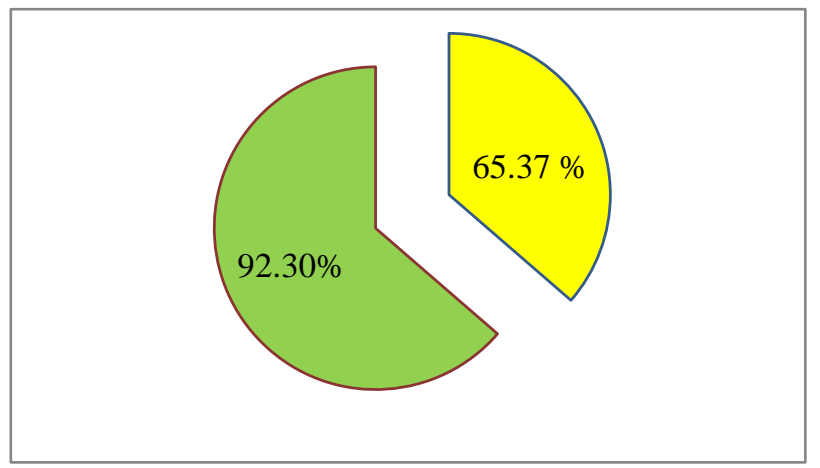

\section{Diagram Batang 1.5. Perbandingan Ketuntasan Siklus I dan Siklus II}

\section{Observasi Siklus I}

Berdasarkan hasil observasi pada siklus I dan II, pada siklus I sudah tampak aktivitas mahasiswa mengikuti pembelajaran, meskipun masih ada mahasiswa yang belum aktif mengikuti proses pembelajaran dengan menggunakan model pembelajaran saintifik approacd. Namun pada 
siklus II mahsiswa sudah optimal dalam proses pembelajaran. Hal ini terlihat pada indikator langkah-langkah pembelajaran yang diamati yaitu menanya, mengamati, mengumpulkan informasi, megelolah informasi dan mengkomunikasikan.

Tabel 1.5 Observasi Aktivitas Mahasiswa pada Siklus I

\begin{tabular}{|c|c|c|c|c|c|}
\hline \multirow{3}{*}{ Aktivitas siswa } & \multicolumn{3}{|c|}{ Kategori Siklus I } & \multicolumn{2}{|c|}{$\begin{array}{l}\text { Kategori } \\
\text { Siklus II }\end{array}$} \\
\hline & \multirow[b]{2}{*}{ Fre } & \multirow[b]{2}{*}{$\begin{array}{l}\text { ST (85- } \\
100 \%)\end{array}$} & \multirow[b]{2}{*}{$\begin{array}{l}\mathrm{T}(65 \\
84 \%)\end{array}$} & & S T 185 \\
\hline & & & & Frek & $\begin{array}{c}- \\
100 \%\end{array}$ \\
\hline $\begin{array}{l}\text { Mahasiswa aktif } \\
\text { melakukan } \\
\text { pengamatan }\end{array}$ & 21 & & 80.76 & 23 & 88.86 \\
\hline $\begin{array}{l}\text { Mahasiswa } \\
\text { membuat } \\
\text { pertanyaan sesuai } \\
\text { dengan hasil } \\
\text { pengamatan }\end{array}$ & 18 & & 69.23 & 23 & 88.86 \\
\hline $\begin{array}{l}\text { Mahasiswa } \\
\text { mengumpulkan } \\
\text { berbagai informasi } \\
\text { dari berbagai } \\
\text { informasi } \\
\text { berdasarkan hasil } \\
\text { pengamatan dan } \\
\text { pertanyaan- } \\
\text { pertanyan yang } \\
\text { telah dibuat } \\
\text { sebelumnya. }\end{array}$ & 19 & & 73.03 & 24 & 92.30 \\
\hline $\begin{array}{l}\text { Mahasiswa } \\
\text { mengelolah } \\
\text { informasi yang telah } \\
\text { didapatkan. }\end{array}$ & 23 & 88.46 & & 23 & 88.46 \\
\hline $\begin{array}{l}\text { Mahasiswa } \\
\text { mengkomunikasikan } \\
\text { hasil pengelolaan } \\
\text { informasi melalui } \\
\text { laporan dalam } \\
\text { media classroom } \\
\text { kepada dosen }\end{array}$ & 24 & 92.30 & & 25 & 96.15 \\
\hline $\begin{array}{l}\text { Mahasiswa } \\
\text { mengkomunikasikan } \\
\text { hasil pengelolaan } \\
\text { informasi melalui } \\
\text { publikasi pada blog- } \\
\text { blog mahasiswa. }\end{array}$ & 20 & & 76.92 & 25 & 96.15 \\
\hline Rata-rata & & & 11 & & 91.79 \\
\hline
\end{tabular}

Selain observasi aktivitas mahasiswa dalam pembelajaran, hasil observasi yang lain adalah hasil observasi nilai-nilai karakter yang muncul dalam pembelajaran dengan menggunakan model pembelajaran saintifik approacd dan berbagai aturan yang ditetapkan dosen dalam pembelajaran yang dapat menumbuhkan berbagai karakter diantaranya dalah karekter disiplin dan tanggung jawab. Hasil observasi karakter mahasiswa dapat dilihat pada tabel berikut:

Tabel 1.6 Observasi karakter disiplin dan tanggung-jawab pada Siklus I

\begin{tabular}{|l|c|c|c|c|}
\hline \multirow{2}{*}{\multicolumn{1}{|c|}{ Karakter Mahasiswa }} & \multicolumn{2}{c|}{$\begin{array}{c}\text { Kategori } \\
\text { Siklus I }\end{array}$} & \multicolumn{2}{c|}{$\begin{array}{c}\text { Kategori } \\
\text { Siklus II }\end{array}$} \\
\cline { 2 - 5 } & Frek & $\%$ & Frek & $\%$ \\
\hline $\begin{array}{l}\text { Mahasiswa datang tepat } \\
\text { waktu di kelas sesuai jadwal } \\
\text { kuliah jam 07.00 pagi } \\
\text { (disiplin) }\end{array}$ & 18 & 69.23 & 24 & 92.30 \\
\hline $\begin{array}{l}\text { Mahasiswa berpakaian rapi } \\
\text { sesuai dengan aturan yang } \\
\text { berlaku (disiplin) }\end{array}$ & 15 & 57.69 & 25 & 96.15 \\
\hline $\begin{array}{l}\text { Mahasiswa setiap } \\
\text { pertemuan membaca doa } \\
\text { sebelum memulai } \\
\text { perkuliahan dipimpin oleh } 1 \\
\text { orang mahasiswa. }\end{array}$ & 21 & 80.76 & 25 & 96.15 \\
\hline $\begin{array}{l}\text { Mahasiswa mengikuti proses } \\
\text { pembelajaran dengan } \\
\text { menggunakan model } \\
\text { pembelajaran saintifik } \\
\text { approacd (disiplin dan } \\
\text { tanggung-jawab) }\end{array}$ & 21 & 80.76 & 24 & 92.30 \\
\hline $\begin{array}{l}\text { Mahasiswa mengumpulkan } \\
\text { tugas yang diberikan oleh } \\
\text { dosen melalui media } \\
\text { classroom sesuai dengan } \\
\text { waktu dan kriteria tugas } \\
\text { yang telah ditetapkan } \\
\text { (disiplin dan tanggung jawab) }\end{array}$ & 24 & 92.30 & 25 & 96.15 \\
\hline $\begin{array}{l}\text { Mahasiswa mempublikasi } \\
\text { hasil tugas mereka pada } \\
\text { blog-blog mahasiswa. }\end{array}$ & 20 & 76.92 & 24 & 92.30 \\
\hline Rata-rata & & & & \\
\hline
\end{tabular}

\section{Refleksi pada Siklus I dan Siklus II}

1. Pada proses pembelajaran dengan menggunakan model pembelajaran saintifik approacd masih banyak mahasiswa yang bingung dengan langkah-langkah pembelajaran yang digunakan, hal tersebut diakibatkan model pembelajaran saintifik approacd yang diterapkan merupakan model pembelajaran yang pertama kali didapatkan oleh mahasiswa. Sehingga dosen terus memberikan arahan dan 
penjelasan mengenai langkah-langkah pembelajaran model pembelajaran saintifik approacd yang belum dipahami oleh mahasiswa. Pada siklus II tidak ada lagi mahasiswa yang bingung dengan model pembelajaran saintifik approacd kerana didapatkan setaip pertemuan dan selalu mendapatkan pengarahan dari dosen.

2. Pada proses pembelajaran siklus I masih ada mahasiswa yang datang terlambat meskipun telah ada kesepakatan dan kontrak perkuliah yang telah disepakati sebelumnya. Hal tersebut diakibatkan oleh berbagai faktor diantaranya (a) Masih ada kebiasaan (habitus) mahasiswa yang selalu menganggap dosen pasti datang terlambat sehingga mereka juga datang terlambat (b) Masih banyak dosen yang tidak memperhatikan keterlambatan mahasiswa, (c) Masih ada dosen lain yang terus-terus memberikan kebijakan kepada mahasiswa masuk keruangan kelas untuk belajar meskipun terlambat, dan (d) Kebiasaan mahasiswa telambat bangun pagi. Semua hal tersebut sangat terkait dengan karakter disiplin mahasiswa yang masih perlu diperbaiki, sehingga setiap mahasiswa yang terlambat diberikan hukuman tidak bisa masuk di dalam kelas mengikuti proses perkuliahan. Pada siklus II mayoritas mahasiswa datang tepat waktu kecuali mahasiswa yang memang tidak perna hadir dalam proses perkuliahan dan mahasiswa yang jauh jarak rumahnya dari kampus.

3. Pada proses pembelajaran siklus I masih ada mahasiswa yang tidak berpakian rapi seperti (a) Laki-laki memiliki rambut panjang, pakai baju kaos dan memakai sandal, (b) perempuan memakain pakaian yang ketat dan rok yang panjang tapi masih kelihatan pendek. Hal tersebut sangat terkait dengan karakter disiplin mahasiswa dalam mengikuti proses pembelajaran sehingga perlu diupayakan memberikan kontrol kepada mahasiswa yang lebih ketat lagi, sehingga pada siklus II tidak ada lagi mahasiswa laki-laki yang memiliki rambut yang rapi, pakai baju kemeja, memakai sepatu dan mahasiswi sudah memakai pakaian yang tidak ketat dan rok yang panjang sesuai aturan.
4. Pada akhir pertemuan siklus I dosen memberikan soal mid semester dalam bentuk essay namun masih ada mahasiswa yang tidak memenuhi satandar kriteria ketuntasan yang telah ditetapkan sebelumnya yaitu 85 yaitu sebanyak $65.37 \%$, sehingga dosen melakukan evaluasi terhadap sosal yang diberikan dan memberikan penjelsan kembali pada aspekaspek yang belum dipahami oleh mahasiswa. Pada siklus II sudah mengalami peningkatan hasil belajar mahasiswa yang telah mencapai 92.30\% dari 26 mahasiswa.

5. Pada kegiatan pengumpulan hasil tugas melalui classroom pada siklus I masih ada mahasiswa yang bingung memasukkannya dalam classroom sehingga harus dibantu oleh teman kelompoknya. Hal tersebut disebabkan media classroom merupakan media pembelajaran yang baru didapatkan oleh mahasiswa, sehingga dosen terus memberikan bimbingan kepada mahasiswa termasuk memberikan tutor sebaya bagi mahasiswa yang belum mengerti dengan media pembelajaran classroom. Pada siklus II hanya 1 orang yang tidak mengumpulkan tugas pada media classroom karena mahasiswa tersebut tidak perna hadir dalam perkuliahan.

6. Selain pengumpulan hasil tugas melalui classroom pada siklus I mahasiswa masih harus melakukan publikasi pada blog-blog masing namun masih ada 5 orang mahasiswa yang tidak melakukan publikasi pada blognya disebabkan belum memiliki blog dan tidak bisa mengoperasionalkan blognya, sehingga dosen juga terus memberikan bimbingan kepada mahasiswa termasuk memberikan tutor sebaya bagi mahasiswa yang belum mengerti membuat dan mengoperasionalkan blognya. Pada siklus II hanya 1 orang yang tidak melakukan publikasi pada blognya karena mahasiswa tersebut tidak perna hadir dalam perkuliahan.

\section{Hasil Angket Mahasiswa}

1. Tanggapan tentang penerapan model pembelajaran saintifik approacd mayoritas mahasiswa mengatakan sangat menyenangkan dengan diterapkannya penerapan model pembelajaran saintifik approacd mereka merasa 
banyak manfaat di antaranya dengan indikator 17 mahasiswa atau $65.38 \%$ yang mengatakan sangat menyenangkan dan 8 orang atau $30.76 \%$ yang mengatakan menyenangkan dan 1 orang atau $3.84 \%$ tanpa jawaban. Selain itu model pembelajaran saintifik approacd menurut 25 atau $96.15 \%$ mahasiswa model ini dapat menumbuhkan karakter disiplin dan tanggungjawab mahasiswa dari langkah-langkah pembelajaran model pembelajaran saintifik approacd sedangkan 1 orang atau 3.84\% tidak memberikan jawaban.

2. Tanggapan mahasiswa tentang media classroom telah menumbuhkan karakter disiplin dan tanggung jawab mahasiswa dengan indikator 23 mahasiswa atau $88.46 \%$ mengatakan karakter disiplin muncul karena tugas dikerkan sesuai dengan waktu yang ditetapkan karena jika melewati batas yang ditetapkan maka media classroom akan menolak tugas dan memberikan laporan kepada dosen terkait keterlambatan mahasiswa mengumpulkan tugas. 21 mahasiswa atau $80.76 \%$ mengatakan karakter tanggung jawab muncul karena setiap pertemuan setiap mahasiswa secara individual dan kelompok mengerjakan tugas dari langkah-langkah model pembelajaran saintifik approacd sehingga mahasiswa menganggap tugas setiap pertemuan merupakan tanggung jawab mereka.

3. Tanggapan mahasiswa terhadap dosen mayoritas mengatakan dosen mengajar sangat menyenangkan dengan indikator 16 mahasiswa atau $61.53 \%$ mengatakan sangat menyenangkan dan 8 mahasiswa atau $30.76 \%$ mengatakan menyenangkan 1 mahasiswa atau $3.84 \%$ mengatakan sedang-sedang dan 1 mahasiswa atau $3.84 \%$ tanpa jawaban.

\section{KESIMPULAN}

Hasil belajar mahasiswa melalui penerapan model pembelajaran scientific approach perbandingan pada siklus I mencapai ketuntasan klasikal hanya mencapai $65.37 \%$ dan pada siklus II sudah mengalami peningkatan sampai $92.30 \%$ mencapai standar ketuntasan klasikal yang telah ditetapkan sebelumnya yaitu $90 \%$. Sedangkan pencapaian ketuntasan secara individual sudah sangat baik mencapai nilai KKM 85 karena diantara 26 mahasiswa hanya 1 mahasiswa yang tidak mendapatkan nilai A dan B karena 1 orang mahasiswa tersebut tidak perna masuk kuliah mulai siklus I dan siklus II. Keaktifan mahasiswa dalam proses pembelajaran aktivitas mahasiswa pada siklus I pada kategori sangat tinggi mencapai 80.11 belum mencapai $90 \%$ tetapi pada siklus II sudah mencapai kategori sangat tinggi yaitu 91.79 sudah mencapai $90 \%$. Hal tersebut mencakup dalam aspek (a) Melakukan pengamatan pada siklus I hanya 21 orang mahasiswa yang terlibat dalam indikator tersebut atau $80.76 \%$ namun mengalami peningkatan pada siklus II menjadi $88.86 \%$ atau 23 orang yang berada pada indikator tersebut, (b) Membuat pertanyaan sesuai dengan hasil pengamatan pada siklus I hanya 18 orang mahasiswa yang terlibat dalam indikator tersebut atau $69.23 \%$ namun mengalami peningkatan pada siklus II menjadi $88.86 \%$ atau 23 orang yang berada pada indikator tersebut, (c) Mengumpulkan berbagai informasi dari berbagai informasi berdasarkan hasil pengamatan dan pertanyaanpertanyan yang telah dibuat sebelumnya pada siklus I hanya 19 orang mahasiswa yang terlibat dalam indikator tersebut atau $73.03 \%$ namun mengalami peningkatan pada siklus II menjadi $92.30 \%$ atau 24 orang yang berada pada indikator tersebut, (d) Mengelolah informasi yang telah didapatkan pada siklus I hanya 23 orang mahasiswa yang terlibat dalam indikator tersebut atau $88.46 \%$ dan tetap pada siklus II menjadi $88.86 \%$ masih 23 orang yang berada pada indikator tersebut, (e) Mengkomunikasikan hasil pengelolaan informasi melalui laporan dalam media classroom kepada dosen pada siklus I hanya 24 orang mahasiswa yang terlibat dalam indikator tersebut atau $92.30 \%$ dan mengalami peningkatan pada siklus II menjadi 96.15\% masih 25 orang yang berada pada indikator tersebut, (f) Mengkomunikasikan hasil pengelolaan informasi melalui publikasi pada blog-blog mahasiswa pada siklus I hanya 20 orang mahasiswa yang terlibat dalam indikator tersebut atau $76.92 \%$ dan mengalami peningkatan pada siklus II menjadi $96.15 \%$ masih 25 orang yang berada pada indikator 
tersebut. Selain itu karakter yang muncul dalam proses pembelajaran melalui model pembelajaran scientific approach yaitu karakter disiplin dan tanggung-jawab pada aspek mahasiswa datang tepat waktu di kelas sesuai jadwal kuliah jam 07.00 pagi, berpakaian rapi sesuai dengan aturan yang berlaku, setiap pertemuan membaca doa sebelum memulai perkuliahan dipimpin oleh 1 orang mahasiswa, mengikuti proses pembelajaran, mengumpulkan tugas yang diberikan oleh dosen melalui media classroom sesuai dengan waktu dan kriteria tugas yang telah ditetapkan dan mempublikasi hasil tugas mereka pada blog-blog mahasiswa. Refleksi siklus I dan II mencakup proses pembelajaran menggunakan model pembelajaran saintifik approacd, kontrak perkuliahan, aturan berpakaian, evaluasi pembelajaran, penggunaan classroom dan publikasi pada blog-blog agar dapat memperbaiki kekurangan dari siklus I menuju siklus II. Hasil angket mahasiswa mayoritas mengatakan (a) Sangat menyenangkan dengan diterapkannya penerapan model pembelajaran saintifik approacd (b) Media classroom telah menumbuhkan karakter disiplin dan tanggung jawab mahasiswa (c) Dosen mengajar sangat menyenangkan.

\section{DAFTAR PUSTAKA}

[1] Arikunto, S. (2010). Prosedur Penelitian. Jakarta. Rineka Cipta

[2] Depdiknas, (2006). Kurikulum Tingkat Satuan Pendidikan. Jakarta : Depdiknas.

[3] Fauziah, R, dkk (2013) Pendekatan saintifik elektronika dasar berorientasi berbasis masalah".Program Studi Pendidikan Teknik Elektro, FPTK UPI. Jurnal INVOTEC, Vol IX,No.2, 165-178.

[4] Insriani, H. (2011). Pembelajaran Sosiologi Yang Menggugah Minat Siswa. Komunitas: International Journal Of Indonesian Society And Culture, 3(1).

[5] Johari.M. dkk. (2014). Pengaruh Pembelajaran Pendekatan Saintifik Terhadap Hasil Belajar Biologi dan Keterampilan Proses Sains Siswa MA Mu'allimat NW Pancor Selong Kabupaten Lombok Timur Nusa Tenggara Barat. e-Journal Program Pascasarjana Universitas Pendidikan Ganesha. Volume 4.

[6] Kemdiknas. (2010). Pengembangan Pendidikan Budaya dan Karakter Bangsa. Jakarta :PuskurBalitbang, Kemdiknas

[7] Kurniawati, D. D. (2010). Pengaruh Metode Mind
Mapping dan Keaktifan Belajar Siswa terhadap Prestasi Belajar IImu Pengetahuan Sosial pada Siswa Kelas VIII Sekolah Menengah Pertama Muhammadiyah 5 Surakarta Tahun Pelajaran 2009/2010 (Doctoral dissertation, Universitas Muhammadiyah Surakarta).

[8] Kulsum, U., \& Hindarto, N. (2011). Penerapan model learning cycle pada sub pokok bahasan kalor untuk meningkatkan keaktifan dan hasil belajar siswa kelas VII SMP. Jurnal Pendidikan Fisika Indonesia, 7(2).

[9] Machin, A. (2014). Implementasi Pendekatan Saintifik, Penanaman Karakter Dan Konservasi Pada Pembelajaran Materi Pertumbuhan. Jurnal Pendidikan IPA Indonesia (Indonesian Journal of Science Education), 3(1).

[10] Marjan, J., Arnyana, I. B. P., Si, M., Setiawan, I. G. A. N., \& Si, M. (2014). Pengaruh Pembelajaran Pendekatan Saintifik Terhadap Hasil Belajar Biologi Dan Keterampilan Proses Sains Siswa MA. $\mathrm{Mu}$ allimat NW Pancor Selong Kabupaten Lombok Timur Nusa Tenggara Barat. Jurnal Pendidikan IPA, 4 (1).

[11] Permendikbud. (2016). Pedoman Pelasanaan Simposium Guru dan Tenaga Kependikan Tahun 2016. Jakarta : Simposium Guru dan TenagaKependidikan.

[12] Putri, N. A. (2011). Penanaman Nilai-Nilai Pendidikan Karakter Melalui Mata Pelajaran Sosiologi. Komunitas: International Journal of Indonesian Society And Culture, 3(2).

[13] Saifudin, A. (2008). Pengembangan Media Pembelajaran Berbasis Komputer Mata Pelajaran IPS SMP. Jurnal Falasifa, 1(2).

[14] Sauri, S. (2010). Membangun Karakter Bangsa Melalui Pembinaan Profesionalisme Guru Berbasis Pendidikan Nilai. Jurnal Pendidikan Karakter, 2 (2).

[15] Situmorang, M. (2014). Pengembangan Buku Ajar Kimia Sma Melalui Inovasi Pembelajaran Dan Integrasi Pendidikan Karakter Untuk Meningkatkan Hasil Belajar Siswa. Prosiding Semirata 2013, 1(1).

[16] Sudrajat, A. (2011). Mengapa Pendidikan Karakter?.Jurnal Pendidikan Karakter,1(1).

[17] Sugiyono. (2011). Metode Penelitian Pendidikan. Bandung : Alfabeta

[18] Wardani, F. T., Ibrahim, M. Y., \& Zakso, A. (2013). Penggunaan Media Gambar untuk Meningkatkan Pemahaman Siswa pada Mata Pelajaran Sosiologi.Jurnal Pendidikan dan Pembelajaran,2(6).

[19] Wardani, T. K. 2012. Penggunaan Media Komik Dalam Pembelajaran Sosiologi Pada Pokok Bahasan Masyarakat Multikultural. Komunitas: International Journal of Indonesian Society And Culture, 4(2).

[20] Wijayanti, A. (2014). Pengembangan autentic 
assesment berbasis proyek dengan pendekatan saintifik untuk meningkatkan keterampilan berpikir ilmiah mahasiswa. Jurnal Pendidikan IPA Indonesia, 3(2).

[21] Towaf, S. M. (2014). Pendidikan Karakter Pada Mata pelajaran IImu Pengetahuan Sosial. Jurnal Ilmu Pendidikan, 20(1).

[22] Tahar, I. (2006). Hubungan kemandirian belajar dan hasil belajar pada pendidikan jarak jauh. Jurnal Pendidikan dan Jarak Jauh, 7(2), 91-101. 